\title{
The Influence of Primitive Religion to the Advent of Philosophy, Science and Applied Orientation in Vietnam
}

\author{
Tran Dinh Thoa ${ }^{{ }^{*}}$, Le Ngoc Thong ${ }^{2}$ \\ ${ }^{1}$ Master. Tran Dinh Thoa, National University of Civil Engineering \\ ${ }^{2}$ PhD. Le Ngoc Thong; National Economics University \\ 3. Professor Dang Nghiem Van (2005), Theory of religion and the religious situation in Vietnam (Reference \\ book), National Political Publishing House, Hanoi: 8.
}

*Corresponding Author: Tran Dinh Thoa, Master. Tran Dinh Thoa, National University of Civil Engineering, Vietnam

\begin{abstract}
By systematic methods of theoretical research, interdisciplinary research, historical logicresearch; abstract - concrete research, etc., the article focuses on three areas: primitive religion, philosophy, science based on the relationship between them.

Results:

1.Primitive religion was indeed one of the elements and origins of philosophy and science.

2.Starting from the movement of the relationships in the above system, the article predicts the new form of the above elements, with the axis considered here is the movement of science.

3.Orienting the application of the above research results in Vietnam: accepting new religious expressions; scientific research in a new spirit; develop philosophy with new methods based on sources: practice; science; sensory perception; rational judgment; Intuitive hunch.
\end{abstract}

Keywords: Primitive religion; Religion; Philosophy; Science; Vietnam

\section{INTRODUCTION}

In the new millennium, the world trend is: peace, stability and cooperation; survival development; integrate but not dissolve. These trends are not only within human society but also between humanity and other material organizations. Religious life is taking place in a very different way from the "traditional". Science has had a transition from Material Science to Post-Material Science. In that context, it is forced to change the overall perception of social consciousness activities with the emphasis on religious consciousness forms (including primitive religion), philosophy and science. Therefore, the study of the influence of primitive religion on the formation of religion and science is indispensable, of great significance in both theory and practice.

\section{RESEARCH METHOD}

The article uses a system of methods: theoretical research, interdisciplinary research, history - logic; abstract - concrete, Expected relationship between the above 3 forms of social consciousness, reflected in figure 1.

\section{RESEARCH OVERVIEW}

In fact, there are many related works, including theories and specific works

Theories: Religious secularization, Geo-religion, Cultural-religious region, on the type of religion. On the other hand, theories are needed: Structure, Entity, Function, Social Nature of religion

Academic works 
Le Cong Su (2006), Philosophy of religion by L Feuerbach. Journal of Religious Studies No.1 and 2 in 2006; I. B. Akulov and O. P. Maluc; Publishing House in 1975; Mal Thomson (2004), Philosophy of Religion, National Political Publishing House, Hanoi, 2004; Russell, Bertrand (1945), A History of Western Philosophy and Its Connection with Political and Social Circumstances from the Earliest Times to the Present Day, Pub. Simon \& Schuster, Allen \& Unwin; Catherine L.Albanese (2012), Religions and beliefs in America, translated by Viet Thu, Thoi Dai Publishing House, 623 pages, 2012; Phillip Goodchild (2002), Law and religion in contemporary society, Ashgate Publishing House, Burlington, 2002;...

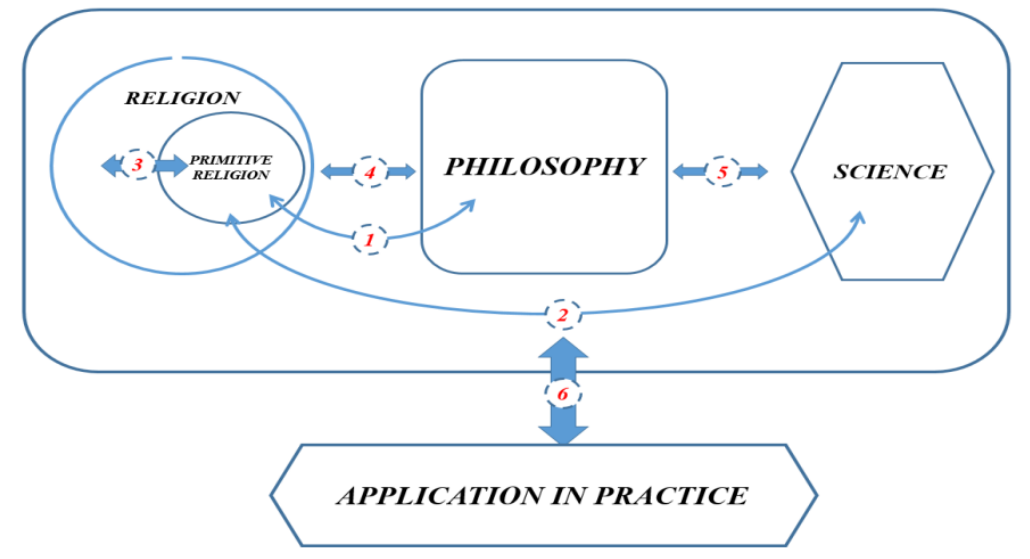

Figure1. Research model

Source: self-built by the author team

Legal works and Web sites. In Vietnam and the world, there are many legal documents on religion and belief.

Comments on related works - Some issues have been studied

*Gradually perfecting the concept, structure and function of primitive religion, philosophy, and science

*Determine more and more fully the relationship between 3 types of social consciousness

*Somewhat mentioning the movement trend of 3 types of social consciousness

That is a very important premise about new manifestations emerging from social consciousness forms for the application and development of the socio-cultural background in the current integration context.

Gaps need further study

* Regarding the methodology: it is necessary to clarify the regularity in the birth of philosophy and science.

*About the content: clarifying the influence of primitive religion on the formation of religion

The above contents become the research tasks of this article

\section{RESEARCH RESULTS}

\subsection{Concepts and relationships}

The actual movement of social consciousness forms has reflected the regularity of the relationship between primitive religion, religion and science:

Primitive religion $\rightarrow$ Philosophy $\rightarrow$ Science

\subsubsection{Religion and primitive religion}

There are many opinions on the concept of religion, we agree:

"Religion is the belief in supernatural, invisible, divine forces that are intuitively accepted to explain worldly as well as non-worldly problems." 
People only learned about religion in the Paleolithic period (about 45,000 years ago). Religion is an objective entity with the basic content of beliefs affecting individuals and communities. Since then, religion often gives absolute values as the goal for people to reach a good life and that content is expressed by rituals, taboos...

Through the perception and production of material wealth - the specific relationship between man and the natural world, man realizes and comes to religion. As an objective entity, religion has undergone a long process of movement in human history: from religion in a classless society (primitive religion) to religion in a class society. That is shown in Figure 2 below:

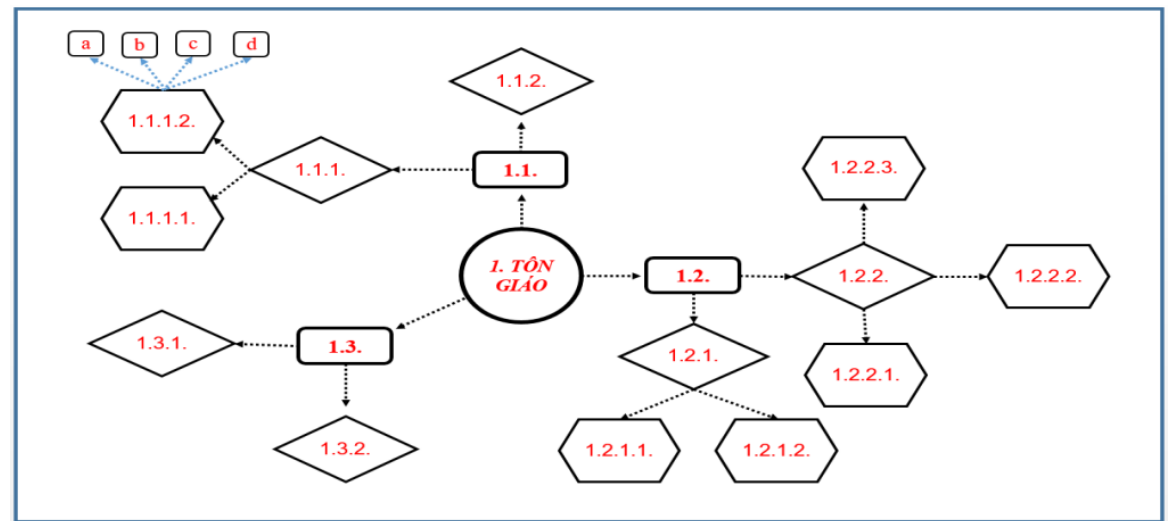

Figure2. Religious genealogical tree

Source: self-built by the author team

\section{In which:}

(1) Religion;

(11) Natural religion;

(111) Primitive religion;

(1111) Mind and matter are identical (animism);

(1112) Mind and matter dichotomous (a. cult of nature; b. cult of all things; c.cult of ghosts and gods; d. cult of Totem);

(112) Polytheism;

(2.2) Moral religion

(2.2.1) Law religion

(2.2.1.1) Brahmin

(2.2.1.2) Jewish religion in early period

(2.2.2) Moral religion

(2.2.2.1) Islamic

(2.2.2.2) GodFairy religion

(2.2.1.3) Jewish religion in later period

(2.3) Popular religion

(2.3.1) Buddhism

(2.3.2) Christianity

\section{With primitive religion}

In primitive society, primitive religion with 5 popular primitive forms: Totemism, Taoism, Magicism, Shamanism, Animism. These five forms have left their mark on religions and religious life today (see table 1) 
Table1.Early forms of primitive religion

\begin{tabular}{|c|c|c|c|}
\hline Seq. & Form & Time of appearance & Description \\
\hline 1 & Totemism & $\begin{array}{l}\text { the last period of } \\
\text { the clan commune }\end{array}$ & $\begin{array}{l}\text { Belief in the close, blood relationship between a group of people } \\
\text { and a certain animal, plant, object, or phenomenon. That is the } \\
\text { ancestor must protect and worship. }\end{array}$ \\
\hline 2 & Taoism & $\begin{array}{l}\text { End of the Stone } \\
\text { Age }\end{array}$ & $\begin{array}{l}\text { Belief in the supernatural of objects (stones, stumps, talismans, } \\
\text { statues, paintings, etc.); acknowledges objects with superhuman } \\
\text { abilities but not human ancestors }\end{array}$ \\
\hline 3 & Magicism & $\begin{array}{l}\text { End of the Stone } \\
\text { Age }\end{array}$ & $\begin{array}{l}\text { Belief that a particular person has the ability to communicate } \\
\text { with the gods (to achieve desires) by symbolic action: } \\
\text { supplications, spells, spells, religious rituals ... }\end{array}$ \\
\hline 4 & Shamanism & $\begin{array}{l}\text { The end of the clan } \\
\text { system }\end{array}$ & $\begin{array}{l}\text { Acknowledge some people have the special ability to mediate } \\
\text { between humans and gods and demons. }\end{array}$ \\
\hline 5 & Animism & $\begin{array}{l}\text { At the end of the } \\
\text { Clan Commune } \\
\text { period. }\end{array}$ & $\begin{array}{l}\text { Acknowledge the existence of the supernatural, the afterlife, and } \\
\text { the spirit. Souls can be beneficial or harmful to humans. All } \\
\text { things and phenomena have souls. }\end{array}$ \\
\hline
\end{tabular}

So, religion and primitive religion are an existence, humans do not create but have the responsibility, discover and implement. Depending on geographical conditions, consciousness and cultural life characteristics of each ethnic group, primitive religions leave their mark on modern religions of ethnic groups.

\subsubsection{Philosophy and science}

Philosophia (Ancient Greek for love of wisdom) appeared simultaneously in ancient Greece, China and India around the 6th century BC. The emergence of religion marked a great development in awareness, in human thought, from perceiving the universe visually to a worldview based on generalized and abstracted knowledge.

Science (Latin word) originally means "education". Scientific research is about finding ways to approach the laws of the universe. Modern science is positive science. Established on an accurate, tested and highly applicable basis, scientific knowledge is a general knowledge system about the world, about the world's movement laws.

Contemporary modern science - material science - was formed in the sixteenth century, with the event of the heliocentric theory of Nicolaus Copernicus.

\subsection{The influence of primitive religion on the formation of Philosophy and science}

\subsubsection{Religion, primitive religion is one of the origins of philosophy}

\subsubsection{From nature.}

"The essence or characteristic of religion is Belief; the nature or characteristic of religion is Knowledge". Should influence on, expressed by the relationship between belief and knowledge.

With its primitive religious nature, philosophical form, Christianity became a popular high-class religion $^{3}$. Part of the philosophical content reflects religion. There are several schools of religion (mainly idealistic religions) that exemplify the doctrine. The pantheism of the Stoic Greek religion complemented the defect of supertheism in Christianity.As such, many religious systems are companions of religion and are influenced by religion in terms of origin.

\subsubsection{Derived from the birth conditions of philosophy}

With the birth of the State, society formed a new system of spiritual values: rationality, sense of personality, morality.... In which, there are religious ideas that have inherited traditional values, reflected in folk compositions, myths and other forms of religious activities. It is the path from paranoid reason to thinking reason, from symbolic expression to conceptual expression. These concepts are partially expressed in primitive religion

\subsubsection{From the social and methodological character of philosophy}

Religion is first of all skepticism, to worship and belief in gods. The answers to the above questions formed philosophy. All religions contain or hint of theistic materialism. On the other hand, some 
religious concepts are formed from the experimental method of spiritual and physical training of religion.

\subsubsection{Derived from the content of philosophical knowledge}

Religion generally reflects the world based on 5 main sources: summarizing practice; recognition of scientific achievements; sensory perception; rational judgment; the philosopher's intuition. Among those requirements of religion has been answered from religion and primitive religion

From the above commentaries, it can be seen that religion, primitive religion has joined the set of origins for philosophy. Religion inherits many elements from religion and primitive religion.

\subsubsection{Primitive religion with scientific formation}

Human culture is based on religion. Famous literary works; The earliest sculptures were all religious products. Chemistry developed in modern times with its roots in alchemy in China. Modern astronomy also derives from the cult of astrology in religious beliefs. The types of social rituals today (sworn oath ceremony; marriage ceremony; etiquette ceremony; ...) are derived from the rituals of ancient religions ${ }^{2}$ : religious rites and priests; spells; rituals in personal life; religious sacrifices; .... The priestly class performed religious rites, instead of interacting with the gods

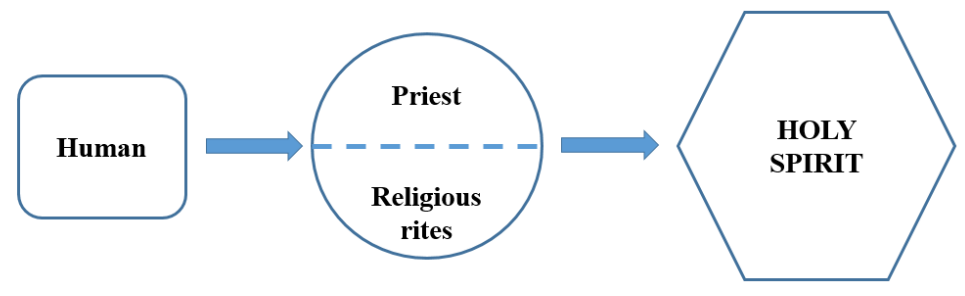

Figure3. Role of the Priestly Class

Source: self-built by the author team

In fact, science has recognized the role of religion - as a necessary emotional need, a faith for human life. Religion was already a separate field in which science could not yet enter. Despite the distance, religion and science still interact. Many religious changes are influenced by science and vice versa. Buddhism uses the dharma of dependent origination, negating the authority of the gods. That's like a hint for science ${ }^{2}$. They both deny and reconcile. Religion plays an important role in patronizing the development of modern science. ${ }^{3}$

Religion has its own goals, but learns from science about methods and means to achieve the goal. Science is made up of people who yearn for truth and knowledge, whose inspiration is partly rooted in religion. Science aims to establish the general laws of the world, first of all from the belief in the existence of such laws. In the minds of Catholics there is always a need to perceive the world, towards science - as a premise for the emergence of science. The main principle (in the religious philosophy of Thomas Aquino) is the harmony between faith and reason, asserting the truth of faith - which is necessary in rational thinking of scientific thinking.

With the scientific nature of philosophical knowledge, each subject of knowledge is recognized as a science when it has its own object and research method; have their own concepts and categories and satisfy the following conditions: Evidence or Rationality; Consistency; Empirical (Experimental, Practical; The Credibility of Empirical material; General Validity (Intersubjectivity); Systematicity (Integrity, Coherence) Among those criteria, there was a contribution from religion.

By religious belief, it is possible to receive meaningful information without going through common sense, transcending the limitations of time and existing space. It also helps to improve, build a loving relationship between people, direct people to good deeds, know how to maintain morality and avoiding evil.

In the above process, religion is the intermediary between religion and science. Religion is the theory of matters that scientific knowledge cannot prove, but religion asserts. If science can thoroughly solve

\footnotetext{
${ }^{2}$ https://thuvienhoasen.org/p87a28636/chuong-2-ton-giao-cua-nhung-dan-toc-chua-khai-hoa

${ }^{3}$ https://vi.wikipedia.org/wiki/T\%C3\%B4n_gi\%C3\%A1o
} 
any of these six problems, then that problem is no longer a religious problem. The above relationships can be expressed through the following model.

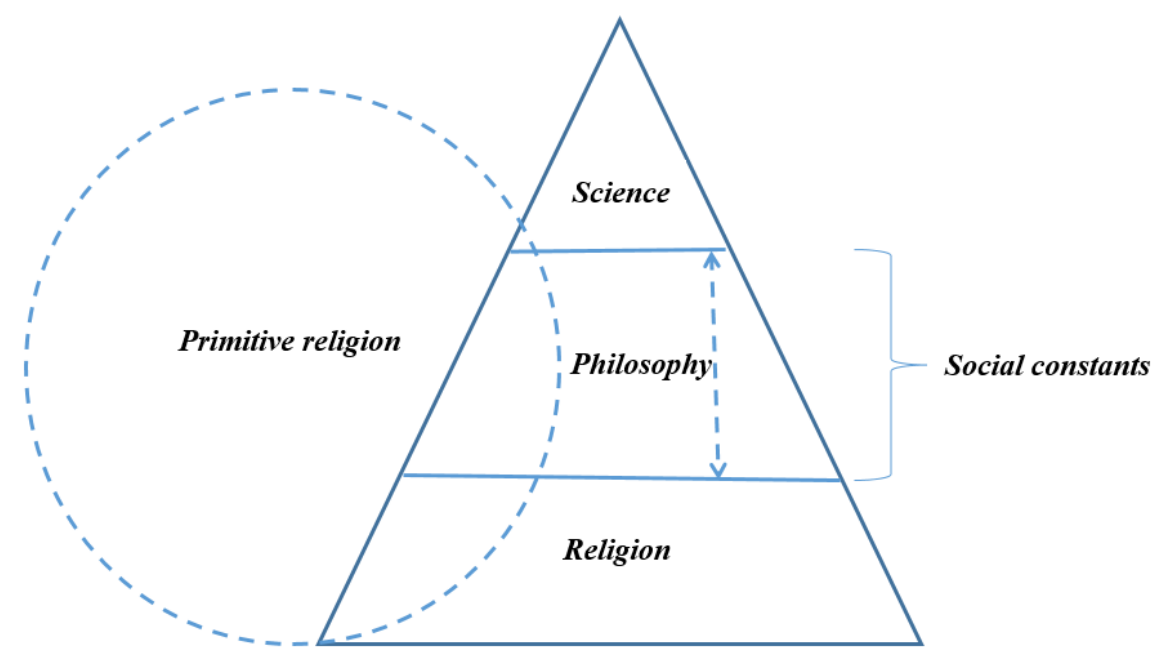

Figure3.Social constants between religion, philosophy and science

Source: self-built by the author team

\section{3. Comments and application orientation in Vietnam}

\subsubsection{Conditions of application in Vietnam}

In Vietnam - a multi-religious country, the movement of religion has dominated social aspects. There are currently 14 religions and 42 religious organizations (recognized and registered by the State), with about 24 million followers, more than 83,000 dignitaries, more than 250,000 positions, 46 training institutions for religious dignitaries, more than 25,000 worshiping establishments ${ }^{4}$, with 06 major religions: Buddhism, Catholicism, Protestantism, Islam, Cao Dai, Hoa Hao 5 .

Vietnam has printed many religious publications and successfully hosted many philosophical events: the 6th World Buddhist Summit in 2010 in Hanoi; Jubilee Year 2011 of the Catholic Church etc. ... Such activities have the legal basis that the freedom of belief and religion of Vietnamese citizens is regulated and guaranteed by the Constitution.

With the concept that everything has a soul, Vietnamese people worship a lot of gods and things related to agriculture and form a belief in fertility; religion of worshiping nature and worshiping people, worshiping ancestors (filial religion). Vietnamese folk beliefs have long-lasting vitality and blend into the orthodox religions of Buddhism, Taoism, Confucianism and Christianity (since the 17th century).

In addition, Vietnam organizes many festivals, each of which consists of two parts: the ceremony means praying and giving thanks, the festival part is a community cultural activity including many games and folk contests.

\subsubsection{Commentary and application orientation in Vietnam - instead of conclusion}

(1)Properly understanding the influence of primitive religion on religion and science helps to improve and build a loving relationship between people, directing people to good deeds, and avoiding evil; strengthen the true belief in the spiritual world, society will "be good in life, good in religion", "live the gospel in the heart of the nation".

(2)The religious-religious-scientific system maintains a constant social connection and operates according to the law of cultural transmission. When science enters a new stage, it is inevitable that

\footnotetext{
${ }^{4}$ Assoc. Prof. Dr. Tran Thi Kim Oanh, Religion - an important discipline of Vietnam and the world, posted on https://vnu.edu.vn/ttsk/?C1654/N27986/Ton-Giao---nganh- Hoc-quan-trong-cua-Viet-Nam-va-the-gioi.htm, April 16, 2021 GMT+7

${ }^{5}$ Information about Vietnam, belief/religion, posted on https://asean2020.vn/web/asean/tin-nguong-ton-giao
} 
religion needs to change to the whole of humanity. Religion also changes to address cognitive challenges. When the science layer is higher, it will pull the lower floors up. Moreover, when religion takes a new step, it stimulates the upper floors. That attracts new premises, new beliefs, new doubts (in the form of new manifestations of primitive religion). A new cycle of movement begins.

(3)The religious-religious-scientific system requires demonstrating and expanding the scope and nature of perception in religion, philosophy, and science, to have a more complete and correct understanding of himself and the place of man in nature and in the universe. At that time, the scientific research on spirituality and spirituality will achieve new achievements

(4)The policy on freedom of religion and belief is based on: the state is secularized; equality of all ethnicities and religions; it's really a private matter: the right to choose one's religion; the right to convert; freedom of thought, belief, religious practice and expression of faith...;

(5)In the new context of the industrial revolution 4.0 and the trend of international integration, at present, it is required that nationalities be active in building a state ruled by law on religion.It is a model of states based on two basic principles of secularism:exercise the right to freedom of religious equality and the principle of separation between the political power of the state and religious organizations ${ }^{6}$.

\section{AUTHOR'S BIOGRAPHY}

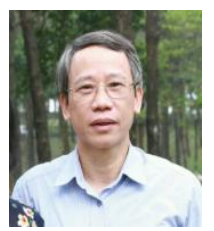

Master. Tran Dinh Thoa, Born: 19/3/1963; Place of birth: Hanoi, Vietnam. Research field: Philosophy; LogicWorking agency: Faculty of Political Theory, National University of Civil Engineering. Phone: 0986722488; Email: trandinhthoadhxd @ gmail.com

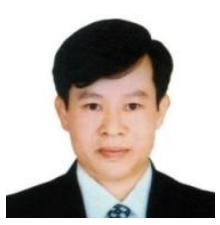

PhD. Le Ngoc Thong, Born: 10/7/1958; Place of birth: NinhBinh, Vietnam. Research field: Philosophy; Logic; Education; Economy Working agency: Faculty of Political Theory, National Economics University. Phone: 0977827786; Email: thongleh@ yahoo.com

\section{REFERENCES}

[1] Do Quang Hung (2008), "Building a secular state model in an environment of religious diversity: the immutable and the mutable - the case of Vietnam", Proceedings of the 3rd Vietnam Studies Conference, Vietnam Culture Subcommittee, VNU Publishing House, Hanoi.

[2] Olivier Bobineau - Sébastien Tank-Storpier (2012), Sociology of Religion, World Publishing House.

[3] Do Quang Hung (2014), “The rule of law and religion”, Vietnam Journal of Social Sciences, No. 3 (76) 2014, p.54.

[4] Olivier Bobineau - Sébastien Tank-Storpier (2012), Sociology of Religion, World Publishing House.

Citation: Tran Dinh Thoa, Le Ngoc Thong. "The Influence of Primitive Religion to the Advent of Philosophy, Science and Applied Orientation in Vietnam" International Journal of Humanities Social Sciences and Education (IJHSSE), vol 8, no. 6, 2021, pp. 65-71. doi: https://doi.org/10.20431/2349-0381.0806010.

Copyright: () 2021 Authors. This is an open-access article distributed under the terms of the Creative Commons Attribution License, which permits unrestricted use, distribution, and reproduction in any medium, provided the original author and source are credited.

${ }^{6}$ Nguyen Quang Hung (2018), On building a state ruled by law on religion. Posted on https://tcnn.vn/news/detail/40832/Ve_xay_dung_Nha_nuoc_phap_quyen_ve_ton_Giaoall.html, August 19, 2018 